\title{
- $\quad$
}

AECU -3544

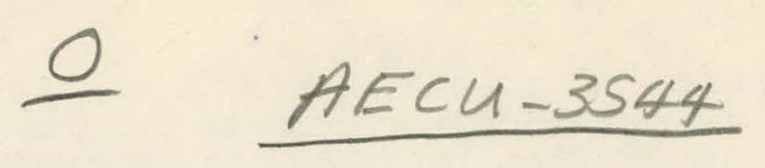

Report No. 16

on

Development of Photomultiplier Tubes

Contract No. AT $(30-1)-1336$

Atomic Energy Commission

P.O. Box 30, Ansonia station

New York 23, New York

Perlod covered by Report $-\infty$ Decomber 1, 1954 to February 28, 1955

AlIen B. Du Mont Laboratories, Inc.

Tube Research Laboratortés

2 Main Avenue

Passaic, NoJ. 


\section{DISCLAIMER}

This report was prepared as an account of work sponsored by an agency of the United States Government. Neither the United States Government nor any agency Thereof, nor any of their employees, makes any warranty, express or implied, or assumes any legal liability or responsibility for the accuracy, completeness, or usefulness of any information, apparatus, product, or process disclosed, or represents that its use would not infringe privately owned rights. Reference herein to any specific commercial product, process, or service by trade name, trademark, manufacturer, or otherwise does not necessarily constitute or imply its endorsement, recommendation, or favoring by the United States Government or any agency thereof. The views and opinions of authors expressed herein do not necessarily state or reflect those of the United States Government or any agency thereof. 


\section{DISCLAIMER}

Portions of this document may be illegible in electronic image products. Images are produced from the best available original document. 


\section{$1 \cdot-$
DEVELOPMENT OF PHOTOMULPTPLIER IUUBES}

A. 3/4" Dianeter Mltiplier Fhotoube me MISS

A number of bubes heve been constructed using Ag-hig dynodes in an attempt to determine whother the low gain fcund in these tubes was due to the procossing or inherent in the sype of multiplier structure. Tabie I Iista 38 tubss and their characteristics. These tubes were all nonstructed as part of the controllod group of tubes. The minimum gatn required is 100,000 at $105 \mathrm{voltis} / \mathrm{stage}$ Nono of the tubes had over 75,000 gain at this voltage and most vere considerably less than thise since the dynodes were activated along with those for larger size tubes, and since these latter dynodes exhjbited satisfactory secondary emis sion ratios, it was concludod that the main difficulty did not lie in the Ag-lig surpaces as sucho It appears on the othor hand that the structure does not Jend itself to good collection efficiency from dynode to dynode.

Under the assumption that electrons from one dvrode may have a high probability of sirtiking the ingide side wall of the succeeding dynode where no Afoing is ordinarily placod, it was decided to build sevoral tubes with Ag-lig covoring the entirs Innor surface of the dynods. These tubes were numbers 4848ED, 4849ED, 4850ID. As seon in Table I eto tho 
ond of this report they e.lso fall short of the desired gain. Another variation in structure was tried. In this case the width of the dynodes was incrsased to $3 / 4^{i \prime}$ without changing the radius of curvature of the dynode. Figure I shows a photograph of a standard inarrow dynode and an exper. imental wider one. These could no:, of course, bo onelosed in a $3 / 4^{\prime \prime}$ diametor blank but were put into a In" bianko Two such tubes were constructed but ons cracked during processing. Tho one tube which was completed had satisfactory character. istics: This tube (tentativeig called tube typo K1359) had a cathode sensitivity of $60 \mathrm{lA} / 1$ and a gain of 109,000 at 105 volts/stage.

Work is nox being initiated to use cesiumwantimony gusfaces in the multipller in ar attempt to bring up the gain of this tube. Along these Ilnes two multiplier phototubes have been constructed using the $3 / 4^{\text {p }}$ dynodes with incroaged width. These are the same shape dynodes used in the K1359. This twibe type has tentatively been called tube type K11.62。 of the two tubes built so far, one has a gain of 425,00 at 84 volis/ stage while the other had a poor gain of 12,000 at 105 volts/ stage. The great improvement in gain available with cesiumantimony dynodes may bring up the gain of the $3 / 4^{i}$ tube to 
its required value. If this js the case it will be necossary to use cesiuinantimong dynodes and accept their inherent disadvantages in order to get the gain.

B. Tube Type K1293

This tube is the $3^{\prime \prime}$ diemeter 12 stage multiplier photom tube with open sidewalls. By open sidewalls is meant that the aluminum coating in this front part of the tube has boen eliminated. As a result a transparent photocathode $\stackrel{\text { s }}{\text { s formed }}$ on that cylindrical part of the bulb between the face plate and shield. Four such tubes have been constructed and their characteristics are shown in Table II.

Table II

Tube No:

$$
\text { PC Sensitivity }
$$

$$
\text { Gain }
$$
$(105$ volts/stage)

5799EC

$$
27.8
$$$$
755,000
$$

5090ED

7.63

$$
I_{2} 180,000
$$

6826110

26.0

$7,650,000$

713IED

37.2

$12,000,000$

All tubes except 5090RD were shippad to $\mathrm{H}_{\circ} \mathrm{E}_{0} \mathrm{C} . \mathrm{N} . \mathrm{Y}_{0} \mathrm{O}_{0} \%$ for evalueition.

C. Glass Beses

Mork hes continued on multiform glass stems a photograph of such a stem is shomn in Figure II. (This was. 
Figure 5 or Repart No. 15 and mas inadvertently Ioft out of this latter report). This ts an oarly attenpt at such stemg. Since this stem was made the dies and muitiforn Flass have bosn obtained and tubes wil. be copstructed shortiy using the plugmin type of stem.

Ac the same time work is in progress to meke a plug. in stem to be used on tubes with cesium antimonj dynodes. A stem is belag designed which can bo uned with the $3 / 4^{\prime \prime}$ mitiplier phototube. It is anticipatod that such a stem will have a metal flange for heliaro sealing and stifx leads for directly plugiging them jnto the socket. D. Tube Type K1306

This is the ultramiolet sensitive multiplier photom: tube which has been constructed for evaluation by the $\vec{A}, \hat{H}$. This tube hes a face plate of high purioy fused sijica. The first guch tube congtructed crebed before the tube could be: evaluated A second tube has baen built ano sent to the A.E. $\mathbb{N}_{0} \mathrm{Y}_{0}, \mathrm{O}_{4}$ for evaluation. This tube had a sensitiviby of 36.1 uAfi and a gain of 1.090 .000 at $205 \mathrm{volts} / \mathrm{stage}$ E. Transit Tine spread Studjes

In undertaking a study of transit time sprsad and. neans for roducing it: special instrumentation becomes necossery por its measurement in experimental oloctron mitipliers. 


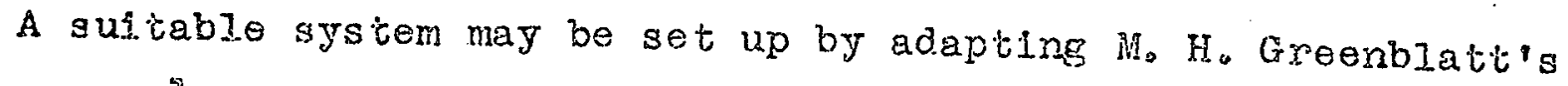
method for measuring time spread in seconcary omission.

The system will use a means for dilrecting short pulises of electrons into an electron multiplist, amplifying the pulses by applying sultable potentials to the dyrodes, and extracting cutput pulses of slectrons for measurelient. With this arrangement it is planned to noasure transiti time spreads in the conventional box dynode structure and in aubsequent Improved types.

The election pulses will be generaied by deriecting, at a radio frequency rato, a boam of elections ncrogs an apertuxe In a metal targot. Pulses of electrons pasing through the aporture will be amplified in an electron miltiplser and sampled by means of an aporture in a latter stage. The sampled pulse will be focused and deflected across a nuito able pickup probe.

In initial transit time spread measuremints on box-trpe dynodes it is expected inat spreads up to $2 \times 10^{-8}$ second will be encountered. Ra doflection froquencies which will. form suitable timo bases are crnvoniuntly available with crystal control. Oscillator instability accordingly will bo reduced.

A phase shifting network using lurnped rasctive components wil be moze feasible at these frequencies than the Ifne

1. Groenbiati, M.H., "On the Reitsuyement of the Averspe Time Spread in Secondary Emission", Guarterly Report Ho. 15, Contract Wo 7405 eng. 26, Sub-308. Electronic Devices for Nuclear Physics, Fab. 1, 1954-Mi y I, 1954。 
gtretcher used by Greenblets st $400 \mathrm{mc}$. LC tark circuits will replace the lecher wires for the deflection plates. Some components, such as the RF power source and cer.taln power supplifes have been obtained for use on this prow ject. The RF source is a transmitter which will deliver severiteen watts up to $85 \mathrm{mc}$. Other components essentie to the system are in various stagos of procurement. F. Summary

Attompts to make a $3 / 4^{n}$ mulitiplier phototube with Ag-Mg dynodes have not proven successpul so far. Various remedies are boing tried and the one which seems to hold out most hope is the use of ceslumantimony dynodes.

Work on plup-in glass.bases is continuing and the equipment necessary for manufacturing them has been obtained. An ultra-violet sensitive tube has been delirered to the A.E.C. for evaluation.

Equipment for measuring transit time sproads in multiplier structures is being set up. Much of the data presented in this report mas taken by Mis. Wayne Nickel.

TUBE, RESEARCH IABORATORIES

Prepared by:
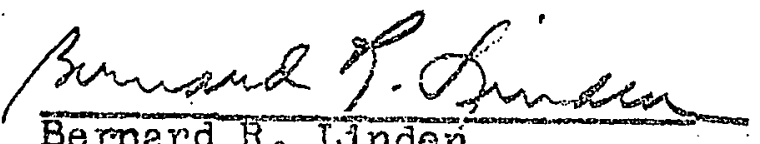

Bernerd R. Lindoy
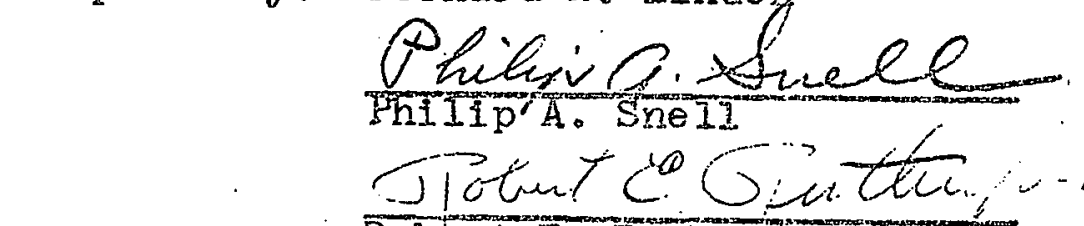

BRI/his

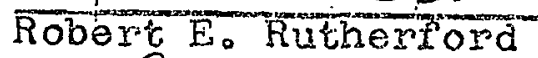

Approved by:

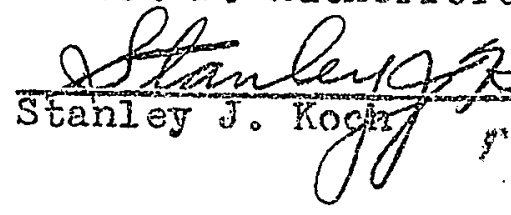




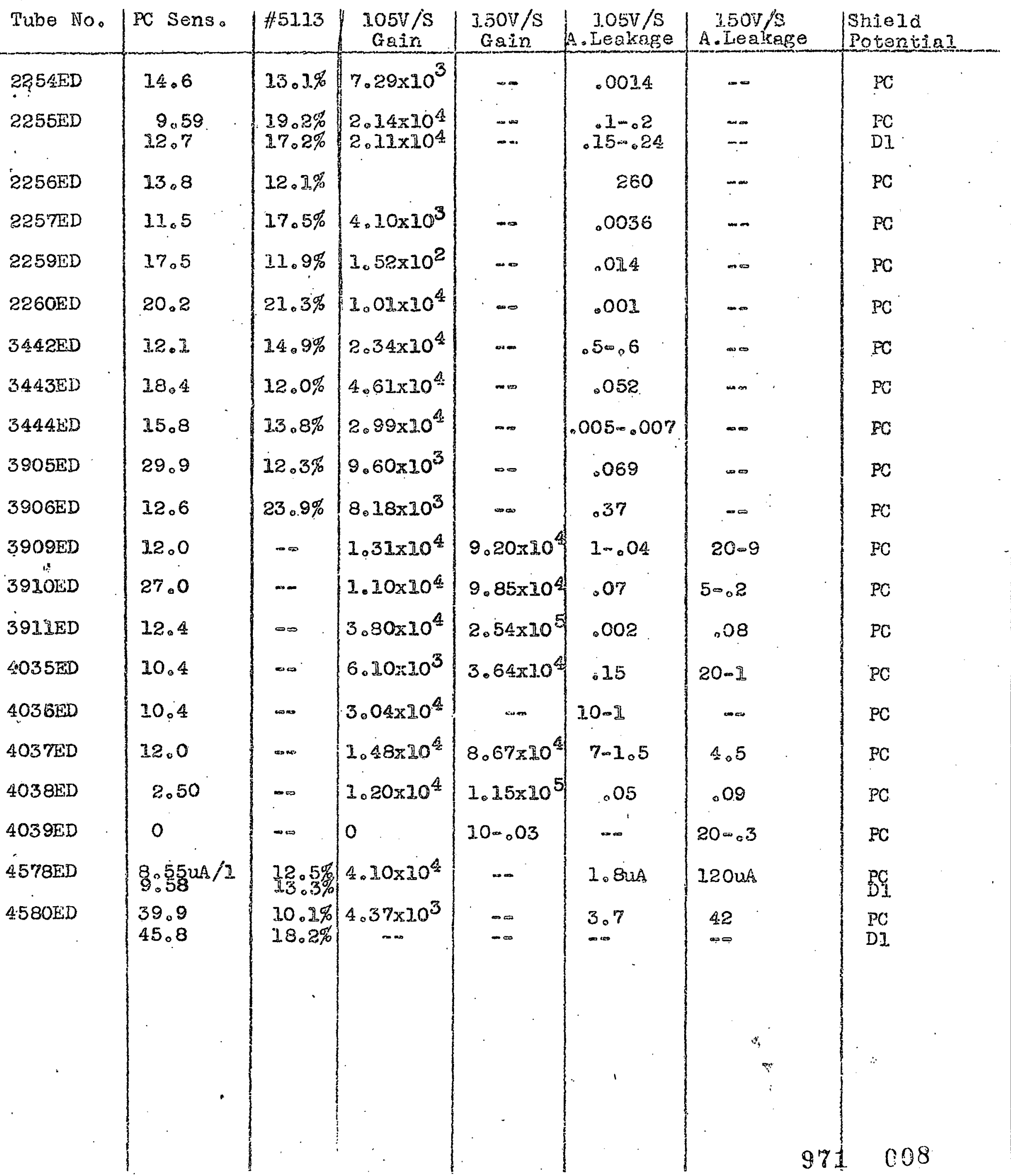


8

TABEE $I$ (cont.)

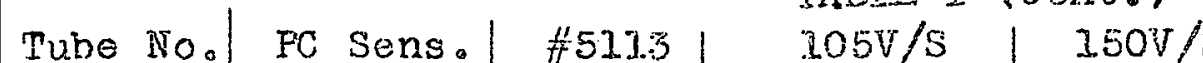

\begin{tabular}{l|l|l|l}
$\mathrm{S}$ & $305 \mathrm{~V} / \mathrm{S}$ & $150 \mathrm{~V} / \mathrm{S}$ & Shield
\end{tabular}

\begin{tabular}{|c|c|c|c|c|c|c|c|}
\hline 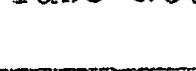 & 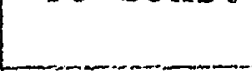 & & Grin & Gain & A.Lealrage & A.Leak. & Potentlal \\
\hline $4.581 \mathrm{ED}$ & $\begin{array}{l}12.8 \\
12.8\end{array}$ & $\infty$ & $\begin{array}{l}8.80 \times 10^{3} \\
6.03 \times 10^{3}\end{array}$ & $-\infty$ & .012 & .10 & $\begin{array}{l}P C \\
D 1\end{array}$ \\
\hline 4582ED & 14.6 & $14.1 \%$ & $3.06 \times 10^{4}$ & $\infty$ & .072 & 2.5 & $P C$ \\
\hline 4583ED & 1.73 & $27.9 \%$ & $1.90 \times 10^{4}$ & $\infty \rightarrow \infty$ & .009 & .43 & FC \\
\hline 458ALD & $\begin{array}{l}39.3 \\
58.3\end{array}$ & $\begin{array}{l}9.96 \% \\
7.86 \%\end{array}$ & $\begin{array}{c}6.74 \times 20^{4} \\
-\infty\end{array}$ & $-\infty$ & .37 & 100 & $\begin{array}{l}\mathrm{PC} \\
\mathrm{DI}\end{array}$ \\
\hline 4847ED & 0.58 & $21.4 \%$ & $6.40 \times 10^{4}$ & $-\infty$ & .23 & 3.8 & IC \\
\hline 484 8ED & 9.97 & $12.4 \%$ & $2.90 \times 10^{4}$ & $\infty$ & 2.3 & 8.7 & PC * \\
\hline $4849 E D$ & 6.80 & $-\infty$ & $2.00 \times 10^{3}$ & $\therefore$ & .25 & 2.5 & PO * \\
\hline 485OED & 2.78 & $19.0 \%$ & $5.60 \times 10^{4}$ & $\infty$ & .085 & .83 & PC \% \\
\hline 5082ED & $\begin{array}{l}0.17 \\
1.40\end{array}$ & $\begin{array}{l}25.0 \% \\
20.9 \%\end{array}$ & $\frac{3.45 \times 20^{4}}{-}$ & $\infty$ & .42 & $\begin{array}{l}18 \\
=\infty\end{array}$ & $\begin{array}{l}\mathrm{PC} \\
\mathrm{DI}\end{array}$ \\
\hline $5083 \mathrm{ED}$ & 10.8 & $11.3 \%$ & $3.31 \times 10^{4}$ & $\infty$ & .30 & 160 & $P C$ \\
\hline $5084 \mathrm{ED}$ & 0.60 & $6.9 \%$ & $9.36 \times 10^{3}$ & $\infty$ & .63 & 5.3 & $P C$ \\
\hline 5085ED & 0.85 & $40.9 \%$ & $2.10 \times 10^{4}$ & $-\infty$ & .32 & .82 & $\mathrm{PC}$ \\
\hline 5524ED & 11.2 & $\infty$ & $1.69 \times 10^{4}$ & $-\infty$ & 5.7 & 370 & EC \\
\hline 5525ED & .304 & $\infty$ & $3.63 \times 10^{3}$ & $-\infty$ & .038 & 38 & $\mathrm{PC}$ \\
\hline 5814ED & $\begin{array}{l}28.7 \\
37.5\end{array}$ & $\begin{array}{l}8.70 \% \\
11.2 \%\end{array}$ & $\begin{array}{c}7.29 \times 10^{4} \\
=-\end{array}$ & $-\infty$ & .92 & $\begin{array}{l}320 \\
\cdots\end{array}$ & $\begin{array}{l}\mathrm{PC} \\
\mathrm{DH}\end{array}$ \\
\hline 5825ED & $\begin{array}{l}12.9 \\
23.8\end{array}$ & $\begin{array}{l}13.1 \% \\
13.9 \%\end{array}$ & $1.11 \times 10^{4}$ & $\rightarrow$ & $\begin{array}{l}.23 \\
-\infty\end{array}$ & 2.3 & $\begin{array}{l}\mathrm{PC} \\
\mathrm{DI}\end{array}$ \\
\hline $7134 \mathrm{ED}$ & 3.83 & $39.1 \%$ & $6.30 \times 10^{4}$ & $-\infty$ & .007 & $\operatorname{sis}$ & $P C$ \\
\hline
\end{tabular}

A Ag Mg on all sidejs within| aynodes. 


\section{9}
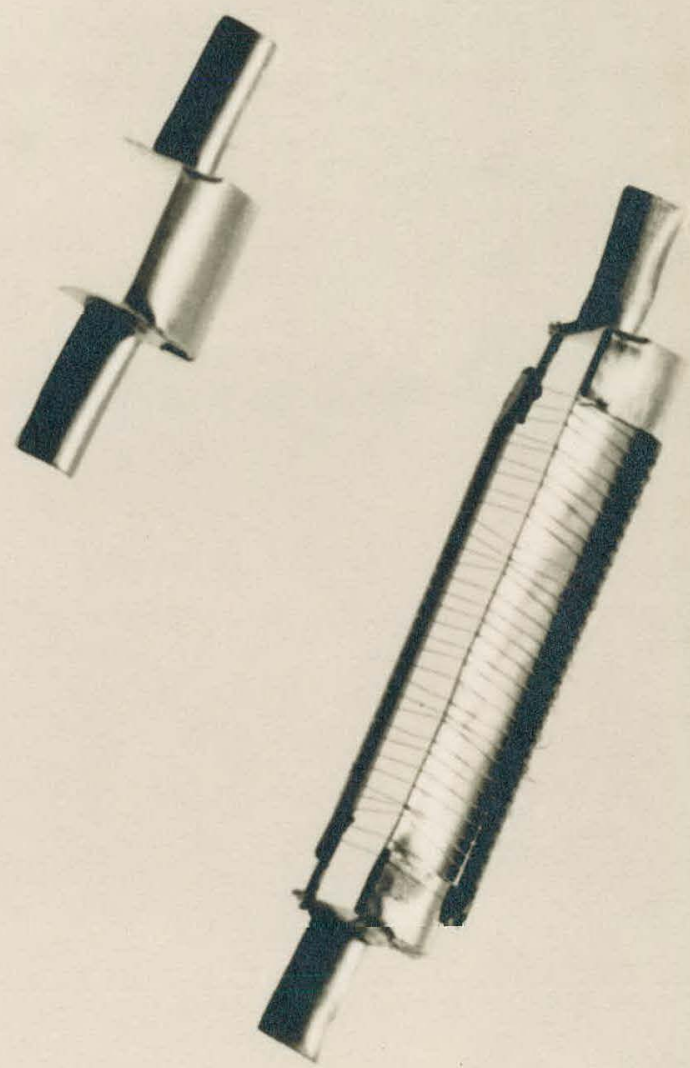

FIG. 1 
10

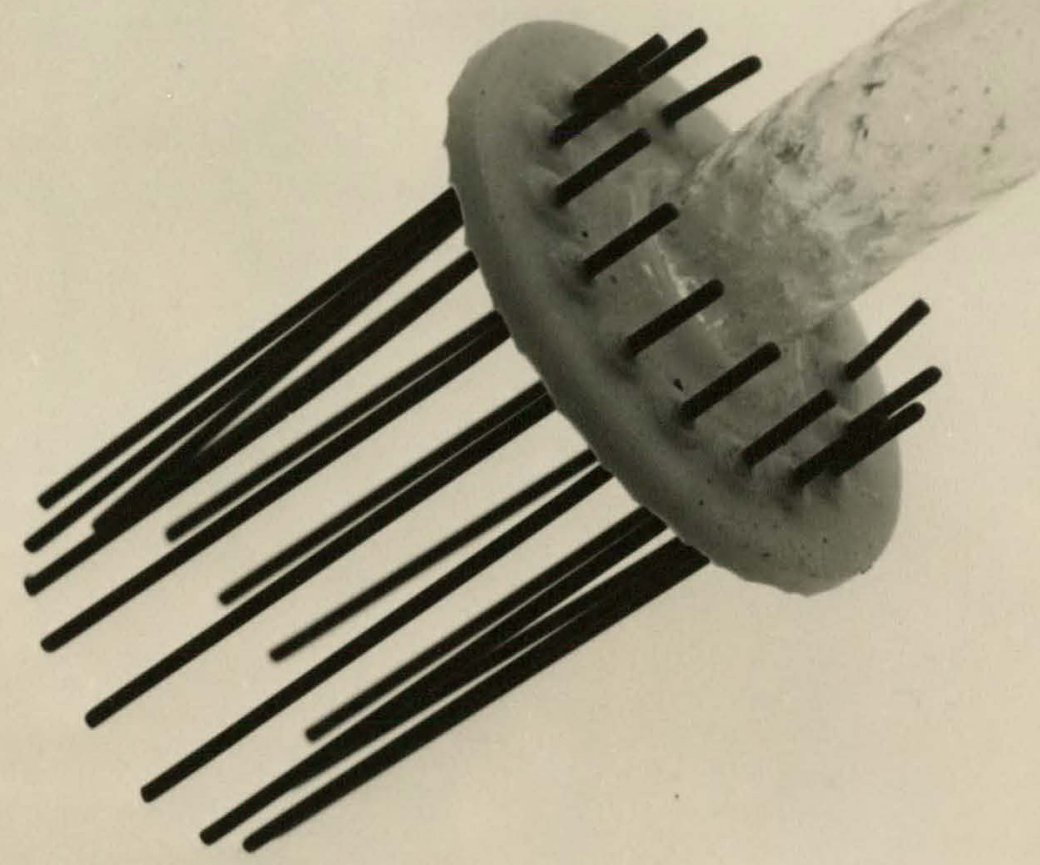

$F \mid G .2$

$971 \quad 011$ 
THIS PAGE

WAS INTENTIONALLY

LEFT BLANK 